\title{
MARKETING STRATEGY: the case of \#curitibasualinda
}

\author{
Brendha Stacy Rangela; \\ Nayla Gabriela Ambrosiob; \\ Thays Cristina Domareski Ruizc
}

\begin{abstract}
AвSTRACT: The brand \#CuritibaSuaLinda is an initiative of Curitiba City Hall, through an action with the Municipal Institute of Tourism and the public transportation company URBS (Urbanization of Curitiba). It was created to replace the former brand of souvenirs Leve Curitiba. Marketing is responsible for the communication and intermediation between the company and its customers. The strategy outlined by the 4Ps are of fundamental importance for marketing planning. The main objective was to identify the marketing strategies of the souvenir brand \#CuritibaSuaLinda. Exploratory research was carried out, with a qualitative approach and descriptive analyses in which a need was perceived for the brand to keep abreast of new market trends and its own marketing positioning. Some shortfalls were seen in relation to the marketing planning, as well as a lack of strategies for its divulgation, particularly in the online environment.
\end{abstract}

\section{KeYWORDS}

Marketing

Tourism destination

Souvenir

Curitiba-PR 


\section{INTRODUCTION}

Curitiba is the capital of the Brazilian state of Paraná, with an estimated population of 1,933,105 (IBGE, 2020), making it the most populous city in the South of Brazil. The city is well-known for its urban planning, environmental programs and public transportation system; elements that gave prominence to the city both national and internationally. It is also an urban tourism destination, and part of the Rota do Pinhão - Curitiba e Cidade Metropolitana Tourist Region (Domareski-Ruiz, Horodyski \& Carniatto, 2019; Municipal Institute of Tourism, 2020).

The brand \#CuritibaSuaLinda is an initiative of Curitiba City Hall, through an action with the Municipal Institute of Tourism and the public transportation company URBS (Urbanization of Curitiba). It was created to replace the former brand of souvenirs, Leve Curitiba, what had existed for nearly twenty years and was located in strategic attractions of the city, such as the Botanical Garden, Ópera de Arame, Tanguá Park, City Center, Afonso Pena International Airport, and the Railway and Bus Stations. The current brand has five physical stores in the capital of Paraná, two of them located in the city center, one in the historical center, one in the Mercês neighborhood and one in the Jardim Botânico neighborhood, close to some of the city's main tourist attractions, such as Largo da Ordem, Passeio Público, Curitiba Panoramic Tower, the Botanical Garden, Municipal Market, Railway Museum, Hauer Shopping Mall and Barigui Park. However, unlike the former souvenir brand, the stores of \#CuritibaSuaLinda are concentrated in the central area of the city, and at the tourist attractions themselves (Image 01).

\section{Figure 01 - Location Map of \#CuritibaSuaLinda Stores}

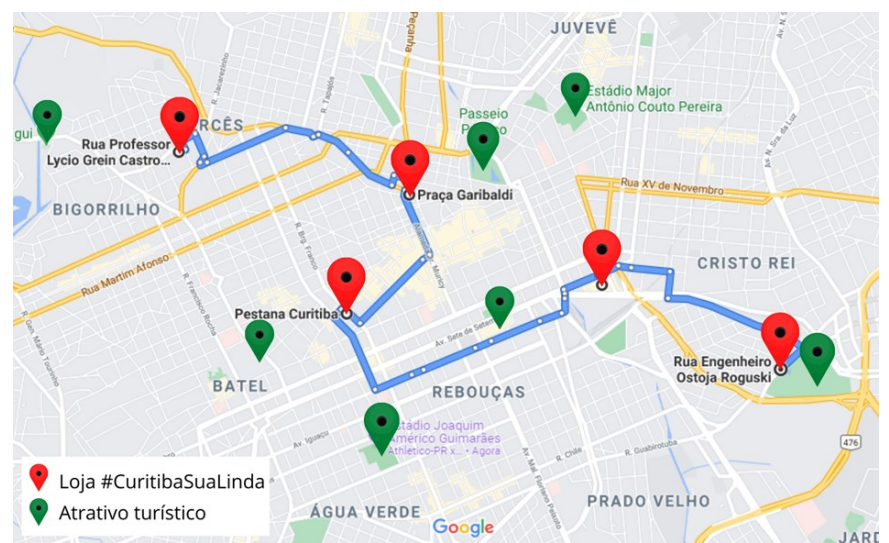

Source: adapted from Google Maps (2020).
The Leve Curitiba brand was managed by the Municipal Institute of Tourism and the Pro-Citizenship Institute. This partnership favored the offer of unique and good-quality products while contributing to social projects, as all earnings from sales of articles were directed to the actions of the Pro-Citizenship Institute. At the beginning of 2018, with the end of the ProCitizenship Institute's contract with the City Hall, the Leve Curitiba stores were closed and replaced by \#CuritibaSuaLinda, created through a project under the mandate of the current mayor, Rafael Greca (Municipal Institute of Tourism, 2020).

Marketing is responsible for communication and mediation between the company and its consumers. It is not restricted to the promotion and sale of a product or service, but is focused on consumer satisfaction (Morrison, 2012). A marketing management plan that includes product, price, place and promotion analysis is important for strategic tourism marketing (Liu \& Chou, 2016). A good marketing positioning strategy considers all these aspects (Adi, 2015). It is a rapidly evolving field and requires professionals to be constantly updated with the latest market trends (Kotler \& Armstrong, 2007; Kotler, Kartajaya \& Setiawan, 2010). The characteristics and activities of an organization focused on hospitality and tourism marketing include identifying client's needs; market research; knowledge of customer perception; analysis of strengths and weaknesses; long-term planning; internal cooperation and liaising with complementary organizations, and performing measurement (Morrison, 2012).

The main objective of this study is to identify the marketing strategies of the \#CuritibaSuaLinda brand. This was done through the following specific objectives: a) to analyze the marketing mix and b) to identify the online strategies used.

This article is divided into 5 sections. The second section describes the research methodology. The third section addresses the concepts of marketing and digital marketing. In the fourth section, the data collected regarding the marketing mix and the online strategies used by the brand are analyzed, presented and discussed. The fifth section gives some final considerations. Bibliographic references are given at the end.

\section{METHODOLOGY}

With the main objective of analyzing the marketing strategies of the souvenir brand \#CuritibaSuaLinda, this research is characterized as exploratory, with a qualitative approach and descriptive and analytical analyses. According to Gil (2008), exploratory research aims to clarify concepts and ideas, providing an overview of an approximate type, about a given fact, while 
descriptive research aims to describe the characteristics of a particular group or phenomenon.

First, a literature review of the subject was carried out, using the search terms: Curitiba; Marketing; and EMarketing. Next, documentary research was conducted based on secondary data, as the main data collection technique. This stage involved researching websites, blogs and market research studies related to the object of study. Finally, unstructured field observation was carried out May 19, 2019, at the store located in the Palacete Wolf, in order to analyze its products and prices (Table 01).

Table 01: Phases of the research

\begin{tabular}{|c|c|c|c|}
\hline \multicolumn{4}{|c|}{ Exploratory Research> Qualitative Approach } \\
\hline \multirow{2}{*}{$\begin{array}{l}\text { Biblio- } \\
\text { graphic } \\
\text { Research }\end{array}$} & $\begin{array}{l}\text { Docu- } \\
\text { mentary } \\
\text { Research }\end{array}$ & \multicolumn{2}{|c|}{$\begin{array}{l}\text { Municipal Institute of Tourism; } \\
\text { Curitiba City Hall; } \\
\text { URBS (Urbanization of Curitiba) }\end{array}$} \\
\hline & $\begin{array}{c}\text { Search } \\
\text { terms }\end{array}$ & \multicolumn{2}{|c|}{$\begin{array}{l}\text { Curitiba; Marketing; E- } \\
\text { Marketing. }\end{array}$} \\
\hline $\begin{array}{l}\text { Data Col- } \\
\text { lection }\end{array}$ & $\begin{array}{l}\text { Unstruc- } \\
\text { tured } \\
\text { observa- } \\
\text { tion } \\
\end{array}$ & \multicolumn{2}{|c|}{$\begin{array}{l}\text { Performed on May 19, } 2019 \text { at } \\
\text { the store located in Palacete } \\
\text { Wolf }\end{array}$} \\
\hline $\begin{array}{l}\text { Descrip- } \\
\text { tive } \\
\text { Analysis }\end{array}$ & $\begin{array}{l}\text { Market- } \\
\text { ing Strat- } \\
\text { egy }\end{array}$ & $\begin{array}{l}\text { 4Ps Strate- } \\
\text { gy: Prod- } \\
\text { uct, price, } \\
\text { place and } \\
\text { promotion }\end{array}$ & E-marketing \\
\hline
\end{tabular}

Source: elaborated by the authors (2020).

Through these phases, it was possible to gain an overview of aspects of the marketing mix of the brand \#CuritibaSualinda in the tourism destination, and to analyze its e-marketing.

\section{MARKETING}

Marketing is the series of activities aimed at gaining an understanding of, and meeting customers' needs (Kotler \& Armstrong, 2007; Kotler, Kartajaya \& Setiawan, 2010). Marketing of tourist destinations can contribute to the organization and structuring of tourism products and services, promotion of tourism destinations, tourist attraction, market segmentation, differential advantage, and visibility and positioning of brand and market. It can also offer customization, create targets, and other aspects related to the marketing mix variables - product, price, promotion and place such as maintaining a good position on the market, among other benefits (Kotler, Kartajaya \& Setiawan, 2010; Chen \& Mathews, 2014).

With the high levels of competition among tourist destinations, analyses of ways to attract and retain consumers have emerged (Schuster \& Dias, 2019). There- fore, destinations should pay attention to the latest trends and to their own positioning and marketing strategies, in order to achieve their objectives of increasing tourist flow and promoting products and services. (Thomaz, Biz \& Pavan, 2014; Roque, Fernandes \& Raposo, 2012).

According to Crescitelli \& Freundt (2013), in order to establish information channels that will influence consumers to purchase something, communication must be organized in a way that convinces them that the goods or services will meet their needs or desires. To this end, the company gathers marketing tools that will produce the desired response in the target market, influencing its demand (Kotler \& Armstrong, 2007). With the popularization of the McCarthy's (1960) marketing mix, practically all subsequent marketing management manuals were organized around the "Ps". Thus, the strategies used are known as "4Ps": Product, Price, Place and Promotion (Mccarthy, 1960; Kotler \& Armstrong, 2007; Kotler; Kartajaya \& Setiawan, 2010).

Kotler \& Armstrong (2007) define the product as something the company offers their target market to meet a need or desire, and which is presented as the basis of the relationship with the customer (Mccarthy, 1960). Price "is the sum of values that consumers exchange for the benefits of obtaining the product" (Mccarthy, 1960; Kotler \& Armstrong, 2007). It is considered the most flexible marketing compound, as the change is easy and quick (Mccarthy, 1960; Gabriel, 2010).

Promotion allows that companies to meet the demand of potential consumers. Therefore, communication strategies are based on the five main tools of promotion: advertising, sales, direct marketing, public relations and personal selling (Mccarthy, 1960; Gabriel, 2010). Promotion is considered to be extremely important, as it gives the product greater visibility, influencing and creating expectations for potential visitors. It is necessary to generate knowledge of the product's existence and its positioning in the target market (Mccarthy, 1960; Gabriel, 2010). The author also mentions that the increase of digital platforms has turned promotion into one of the most complex activities of the marketing mix. Meanwhile, place covers issues such as the actual sale of the products, and sale strategies for the target audience, product and company (Mccarthy, 1960). Various researchers have conducted studies on electronic distribution channels as marketing tools to expand their businesses (Corrêa, 2014; Júnior, Sousa, Demo, 2018) through online marketing.

Therefore, marketing is a topic of imperative importance in tourism, as it represents the main influence of management that impacts directly on the global market (Middleton, 2002), where communica- 
tion is multidirectional and multimedia and is in several channels, simplifying access to information (Wichels, 2014).

\section{Online Marketing or E- MARKETING}

Nowadays, the internet is essential for our information, as it has brought new forms of communication, with the supply of direct, simultaneous content. It has transformed the process of purchasing tourism products and services. On a daily basis, the internet receives thousands of important news items, meeting the needs of a generation that is constantly searching for up-todate and specific content. Technological resources provide the development of innovative products, as well as a new perspective for their distribution (Font, 2009). So, the internet presents itself as a complete instrument, mainly due to the possibility of consumer interactivity it affords, as well as offering access to an enormous wealth of valid information for both customers and organizations (Akel, 2012). E-marketing is the process of promoting online actions in order to reach customers through internet-based tools (Li \& Buhalis, 2005).

Placing marketing in the context of this new digital scenario, we can see its importance in virtual spaces, as society is becoming increasingly dependent on digital technology, especially when it comes to social media and forms of purchase and product sales. Therefore, companies must adapt, and find new forms of consumption and e-marketing (electronic marketing).

E-marketing, according to Reino (2012), is the application of the marketing concept in the digital environment, including tools such as websites, advertisements, e-mail ads and blogs, to understand and meet customers' needs. Boaria, Anjos \& Raye (2014) state that investment in e-marketing brings a series of benefits. For example, strengthening the brand, increasing consumer interaction, and creating content, among others. Within Tourism, Thomaz, Biz \& Pavan (2014) emphasize that tourism organizations must be aware of new social media marketing strategies to promote products, services and tourist destinations. The authors also state that online information allows much faster dissemination, generating interaction between people, communities and organizations, which is an excellent marketing strategy (Thomaz, Biz \& Pavan, 2014).

As for social media websites, according to Gabriel (2010), these are broad and complex social structures, due to the evolution of information and technological communications. However, the author also points out that the essence of social media is people, and human connections, not only technology. Social media sites such as Facebook, Twitter, YouTube and Flickr are con- sidered the world's leading websites, each with their different user bases (Gabriel, 2010). Therefore, the importance of retail companies being present on the social networks is related to the use of these networks to interact with people, in this case potential customers, through electronic websites (Eugênio, 2015).

Technology has transformed the market and the way consumers interact with brands, companies and products. The online format, based on digital platforms, determines the strategies to reach this consumer (Kotler, Kartajaya \& Setiawan, 2010).

\section{MARKeting Mix}

To identify the marketing strategies used by the souvenir brand \#CuritibaSuaLinda, this study analyzes the marketing mix proposed by the store, through its use of the "4Ps": Product, Price, Place and Promotion (Mccarthy, 1960; Kotler \& Armstrong, 2007).

\section{Product}

The brand \#CuritibaSuaLinda offers a wide range of products manufactured by over seventy-five artisans, designers and artists from Curitiba and the surrounding area that depict or refer to the city, its tourist attractions and specific customs, such as the local dialects. The purpose of these products is to stimulate a creative economy and promote handmade production (Municipal Institute of Tourism, 2020). The selection and curation of products approved for sale is carried out by a team from the Curitiba City Hall.

The products available for sale are produced by over seventy-five artisans, designers and artists from Curitiba and the surrounding area (Municipal Institute of Tourism, 2020). Over two hundred unique, high-quality products themed around the city and its attractions are sold in the stores. The pieces are handmade, handcrafted and exclusive, with a range of prices, starting from R\$ 2.00 (two Brazilian reals) (URBS, 2020).

The purposes of the products are to help tourists materialize and preserve their experiences during their visit to the Paraná capital, and to idealize the local residents' sense of belonging. The items are selected following strict criteria, by representatives of the Municipal Institute of Tourism, the Cultural Foundation of Curitiba, and other local government organizations. It is also emphasized that the products must have some necessary requirements in order to be approved for selection, such as quality, creativity, originality, agreement with the legislation, innovation, environmental awareness and association with tourism and local culture (Bem Paraná, 2018).

Hence, the stores sell handcrafted, semi-handcrafted 
and artistic products, such as decorated eaves, and fir cones placed playfully in niches and corners. They also contain around a hundred and fifty items of clothing, accessories, jewelry, decoration, housewares, books, stationery, toys, key chains, luggage tags and fridge magnets bearing classic images of the city, or humorous local words and sayings (Municipal Institute of Tourism, 2020).

Figure 01, 02 and 04 - Key chains and Fridge magnets from the store \#CuritibaSuaLinda

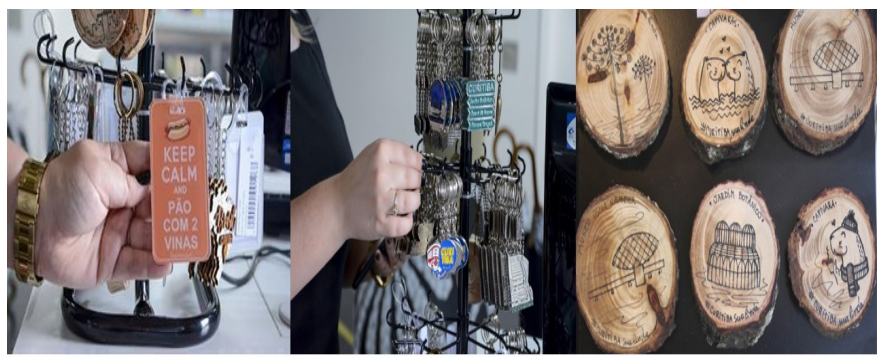

Source: Municipal Institute of Tourism (2020) and URBS (2020).

The best-selling products are a custom-made mug with a Curitiba Periodic Table and the petit-pave umbrellas (Mcities, 2018). The first depicts words in the local dialect, such as vina, guria, japona, and bolacha. The second, the umbrella, comes with two types of pattern: one "with a pattern of colorful stylized pine nuts, created in the 1920s by the sculptor João Turin (18781949), considered the father of the Paraná style of architectural decoration" (Curitiba City Hall, 2018) and the other with the petit-pavé pattern in black and white, representing Curitiba's sidewalks, the work of the artist Lange de Morretes (1892-1954), who was one of those responsible for the creation of the Paranista movement (Curitiba Space, 2019).

Figure 05 and 06 - Curitiba Periodic Table Mug and the Petit-pavê Umbrella

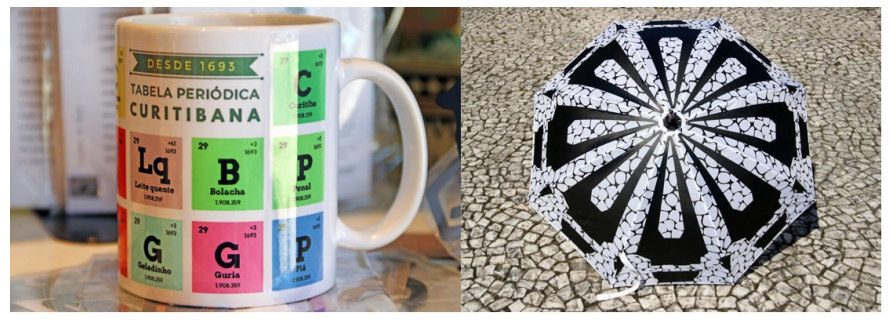

Source: URBS (2020) and Municipal Institute of Tourism (2020).
Besides the items already mentioned, the brand also has permanent collections such as "City Attractions", "Culture and ethnicities", "Four seasons in a single day", "Geological Site and Zoo" and "\#CuritibaSuaLinda". During the year, other themed collections are launched linked to the seasons - Spring, Summer, Fall and Winter - and holidays e.g., Christmas and Easter (Municipal Institute of Tourism, 2020). We can therefore see that the tourist image of the city is associated with its urban planning and in particular, with some of its parks, such as the Botanical Garden and Opera de Arame, or with cultural attractions, such as the Oscar Niemeyer Museum, which are depicted on the souvenirs offered by the commercial establishments of these products (Horodyski, 2014).

\section{Price}

Price is the only element of the marketing mix that generates income, being one of the most flexible elements (Kotler \& Keller, 2006). The prices of items in the \#CuritibaSuaLinda store at Palacete Wolf, one of five stores in Curitiba, were analyzed. Prices range from $R \$$ 2.00 for a postcard, to $R \$ 3,800.00$ (Brazilian reals) for a framed picture. The table 02 shows the main products and their prices, in ascending order.

Table 02: \#CuritibaSuaLinda store prices

\begin{tabular}{|l|c|}
\hline \multicolumn{1}{|c|}{ PRODUCTS } & $\begin{array}{c}\text { PRICE (in } \\
\text { Brazilian } \\
\text { Real - R\$) }\end{array}$ \\
\hline $\begin{array}{l}\text { Postcards; Magnets: wood and plastic; Key } \\
\text { chains; Bookmarks; Cup holders; Cups; Cus- } \\
\text { tomized socks. }\end{array}$ & $\begin{array}{c}\text { up to R\$ } \\
25.00\end{array}$ \\
\hline $\begin{array}{l}\text { Eco bags; Magnetic cup holders kit; Mugs; } \\
\text { 4D Araucaria Puzzles; Key holders. }\end{array}$ & $\begin{array}{c}\text { up to R\$ } \\
50.00\end{array}$ \\
\hline $\begin{array}{l}\text { Ukrainian handcrafted crafts; T-shirts; Note- } \\
\text { books and diaries; Vanity cases, Cases, Wal- } \\
\text { lets and Coin pouches. }\end{array}$ & $\begin{array}{c}\text { up to R\$ } \\
80.00\end{array}$ \\
\hline Umbrella and Pictures. & $\begin{array}{c}\text { up to R\$ } \\
120.00\end{array}$ \\
\hline Pictures. & $\begin{array}{c}\text { up to R\$ } \\
3,800.00\end{array}$ \\
\hline
\end{tabular}

Source: elaborated by the authors (2020).

Based on this analysis, we find a wide range of prices. There are products to suit those with high or low purchasing power, and the range of products and prices has the potential to increase consumer spending in the store. 
Place

\#CuritibaSualinda stores can be considered retail outlets, as they sell products to the final consumer for their personal use (Kotler \& Armstrong, 2007). Success in retail sales requires a good choice of location, as ease of access is of primary importance to the target market, aiming for areas that are compatible with the positioning of the trade. (Kotler \& Armstrong, 2007). The chain has five physical stores in the Paraná capital. These are located in the city center, in the historical center, in the Mercês neighborhood and in the Jardim Botânico neighborhood. The stores are located close to some of the city's tourist attractions, such as Largo da Ordem, the Botanical Garden, Curitiba Panoramic Tower and the Municipal Market. Next to these attractions, there are also the Railway Museum, Hauer Shopping Mall, Barigui Park, Passeio Público and the stadiums of the main soccer clubs in the capital (Major Antônio Couto Pereira Stadium of the Coritiba Foot Ball Club, Durival Britto e Silva Stadium, also known as Vila Capanema, home of Paraná football club, and the Joaquim Américo Guimarães Stadium, popularly known as 'Arena da Baixada', home of Athletico Paranaense).

Figure 07 and 08 - Palacete Wolf and Jardim Botânico Stores

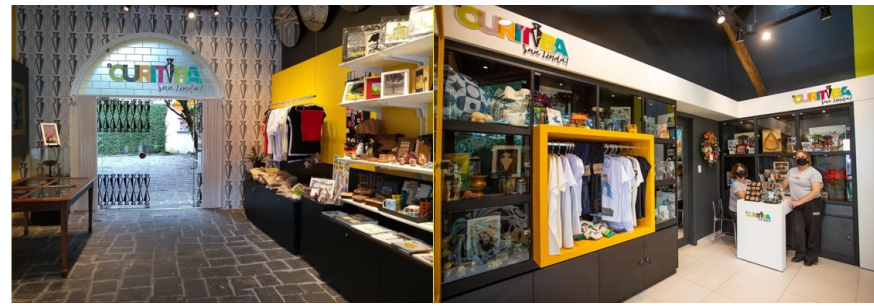

Source: Curitiba City Hall (2020).

The first store was opened on September 20, 2018, at the Palacete Wolf, located at Garibaldi Square in the Historical Center, where the headquarters of the Municipal Tourism Institute is now located. Its opening hours are Tuesdays to Fridays from 9 am to 5:30 pm, Saturdays from 9 am to $1: 30$ pm, and Sundays from 9 am to 2:30 pm (Curitiba City Hall, 2019).

The second store to be opened was the Curitiba Panoramic Tower, located in the Mercês neighborhood. Its opening hours are Tuesdays to Fridays from 10 am to 6 pm and Saturdays and Sundays from 12 pm to 6 pm (Curitiba City Hall, 2019).

The third store was opened on January 21, 2019, located in the Municipal Market. It opens on Tuesdays to Saturdays from 9 am to $6 \mathrm{pm}$ and on Sundays from 9 am to $1 \mathrm{pm}$. Like the other stores, it does not open on
Mondays (Curitiba City Hall, 2019).

Located at David Carneiro Cultural Space - annexed to the Pestana Hotel Event Center, the fourth store is the largest of one. It has slightly different opening hours from the other stores: Mondays to Fridays from 9 am to $6 \mathrm{pm}$. It does not open on weekends (Curitiba City Hall, 2019).

In 2019, the opening of 5 more units was planned to serve tourist areas of the city such as: the Botanical Garden, Tanguá Park, Barigui Bistro, Cine Passeio and the Zoo (Curitiba City Hall, 2020). Of these, the only one to open was the one at the Botanical Garden, which was inaugurated on December 3, 2020. It opens on Mondays to Saturdays, from 10 am to $5 \mathrm{pm}$ (Curitiba City Hall, 2020).

Our analysis shows that the brand has very few sores and consequently, even though they are in the most central areas, they are poorly distributed throughout the city. For example, of the twenty-three stops of Linha Turismo, with its double decker buses that circulate around the main tourist attractions of the city, \#CuritibaSualinda is present in only 4 of them: Palacete Wolf in the historical sector, the Botanical Garden, the Panoramic Tower, and the Municipal Market. The attractions most frequented by tourists are the Curitiba Panoramic Tower, the Oscar Niemeyer Museum, the Botanical Garden and Tanguá Park - of which \#CuritibaSuaLinda is present in only two. Embracing the potential space of the other attractions would enable it to reach a wider range of consumers.

\section{Promotion}

The promotion strategy for \#CuritibaSuaLinda resulted in the exhibition "Curitiba, Sua Linda", promoted by URBS, the Municipal Institute of Tourism and the Municipal Social Communication Secretary. The campaign adorned the city's tube bus stops, emphasizing the brand's name, throughout the first semester of 2019 (Curitiba City Hall, 2019). These spaces were used to display images of tourist attractions in the city.

Figure 09 and 10 - Exhibition "Curitiba, Sua Linda" on bus stops

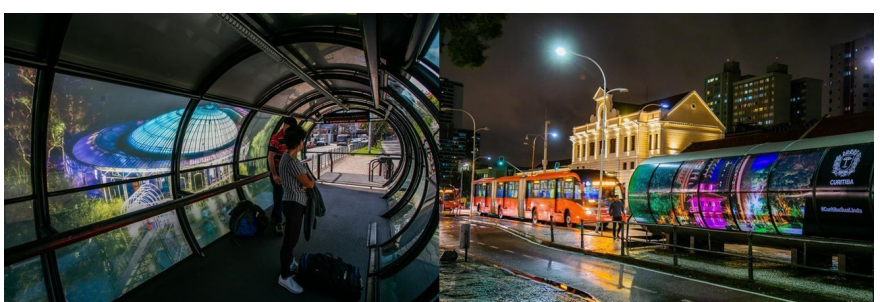

Source: Curitiba City Hall (2019). 
It is interesting to highlight that the choice of locations for this promotion - bus stops - are in themselves, a symbol of the city. This directly impacted the quality, marketing and sustainability associated with the tourist activities in Curitiba, as stated by Souza \& Gandara (2013) in their study that analyzes the impact of urban facilities on the tourist destinations of Curitiba. Montenegro (2005) points out that bus stops are considered a national and international symbol, but for the local population, they are esthetically accepted without the innovative meanings attributed to them by the City Hall. Therefore, local tourism is also promoted with the display of images in the bus stops, as this is an opportunity to increase interest among the local residents, who have not yet visited the attractions (Curitiba City Hall, 2019).

The store openings were also used as promotional events, with the presence of the mayor and the first lady. The most outstanding one was the opening of the fourth store at the David Carneiro Cultural Space, annexed to the Pestana Hotel Event Center, which was part of Curitiba's 326th birthday celebrations and was marked by a conceptual fashion show with designs inspired by artists from the city and pieces by local artists (Municipal Institute of Tourism, 2019). Special promotions are carried out in the stores on special commemorative dates, such as Mother's Day, Father's Day, Valentine's Day and Christmas.

\section{Online Strategles}

The \#CuritibaSuaLinda brand does not use ecommerce, relying solely only on the five physical stores mentioned above. Because it is a company that sells souvenirs, the focus is on face-to-face sales; however, the idea of electronic commerce has not been ruled out.

Concerning social media services, \#CuritibaSuaLinda has an Instagram account (@lojacuritibasualinda) with 222 publications (as of the day of analysis) and approximately 1,700 followers. The page promotes products through its posts and provides information about the stores' opening hours. The Instagram account also makes use of hashtags as a promotional strategy - the main ones used are: \#curitilover, \#curtacuritiba, \#lojacuritibasualinda, \#CuritibaSuaLinda and \#LojaCuritibaSuaLinda.

The account has low engagement, currently with an average of around sixteen likes per publication, i.e., engagement of $0.96 \%$ (average likes divided by the number of followers). The local City Hall is considering hiring an intern in the area of communications, to keep the page updated.

While looking up for "\#CuritibaSuaLinda" on Google, the initial results were from a blog with the same name as the brand, Curitiba Sua Linda. The blog in question has the rights reserved since 2016 and can be found on other social media services, such as Instagram and Facebook. However, the website is not associated with the souvenir brand; is a tourism blog with photos of the main tourist attractions. Compared with the store's Instagram, the social medial of the Curitiba Sua Linda blog has greater engagement, with over 1,400 posts and more than 11,000 followers.

Searching on Google, the \#CuritibaSuaLinda website does not appear at first, and the easiest way to find it is through the brand's Facebook page. The website is still under construction, with little information about the products and no area for online sales. Its Facebook page has around 500 likes, and again, little public engagement in its posts.

Table 03: Analysis of its presence on Social Media

\begin{tabular}{|l|c|c|}
\hline \multicolumn{1}{|c|}{ Social Media } & $\begin{array}{c}\text { Existing } \\
\text { Account }\end{array}$ & $\begin{array}{c}\text { Number of likes / fol- } \\
\text { lowers / accesses }\end{array}$ \\
\hline Facebook & Yes & 527 likes \\
\hline Instagram & Yes & 1.737 followers \\
\hline Twitter & No & - \\
\hline E-commerce & No & - \\
\hline Official Website & Yes & undisclosed \\
\hline
\end{tabular}

Source: elaborated by the authors (2020).

It is also interesting to point out that as a result of the souvenir brand, the hashtag \#CuritibaSuaLinda became a tourist brand of the city itself. The hashtag on Instagram had (as of the date of this study) more than 80,000 posts, the majority with pictures of tourist attractions in the city of Curitiba.

\section{FINAL CONSIDERATIONS}

The main purpose of this study is to identify the marketing strategies of the brand \#CuritibaSuaLinda, analyzing its marketing mix. The analysis of the "4Ps" was created in a scenario where physical products, physical distribution and mass communication prevailed. Nowadays, with the transformation of the business environment brought by the new digital contexts, the marketing mix model is changing (Dominici, 2009).

Despite bringing a proposal to valorize local producers and artists with products that represent the city of Curitiba, it can be seen that the brand \#CuritibaSuaLinda 
needs to focus on new market trends and its positioning (Thomaz, Biz \& Pavan, 2014).

Having identified the marketing mix using the strategy known as the "4Ps": Product, Price, Place and Promotion, some conclusions can be drawn. Product, according to Kotler and Armstrong (2007), is something the company offers its target market to meet a need or desire. Therefore, for \#CuritibaSuaLinda this is the strategy that most stands out, as the products express the identity of the city, with images of the main attractions depicted on the souvenirs and produced by local artists. For this reason, marketing is not only focused on the price of the product, but contributes directly to new product dimensions, such as value, identification, image and brand reputation (Kotler, Kartajaya \& Setiawan, 2010).

Regarding price, it is known that this is directly related to customer satisfaction. With the increasing availability of information, and high levels of competition in the tourism sector, today's consumer is more demanding. Companies define their prices based on market monitoring and competition analysis (Machado, Camfield, Cipolat \& de Quadros, 2012). Thus, \#CuritibaSuaLinda presents a wide range of prices, catering for different types of consumers. As it is a souvenir brand, all other local souvenirs and handicraft stores are its direct competitors, especially those located in the historical center, at tourist attractions and at the points of arrival and departure of visitors, such as the airport and bus station.

Place, on the other hand, is seen as the most fragile strategy of the marketing mix for the brand, as it has only five stores, and these are located only in the central area of the city. As many of the most popular attractions are distributed all across the city, this concentration of stores means there is no outlet, for example, at the main points where tourists arrive and leave - the airport and the bus station. Placing the products of the brand at these points is essential to catch last-minute purchasers, i.e., tourists who forgot to buy a gift or souvenir, and end up looking for one at the last minute.

Promotion is, essentially, focused on the points of sale - the physical \#CuritibaSuaLinda stores, as the brand has little online participation. Its Facebook and Instagram pages could highlight the artisans who produce the handicrafts, perhaps focusing on particular souvenirs that are directly related to the image of Curitiba. While conducting this study, some inadequacies were noted in relation to the network's marketing planning, as well as a lack of strategies for its dissemination and promotion, especially online. The research concludes that digital strategies in social media websites are not reaching their goal of generating interaction between people, communities and organizations, which are an excellent marketing strategy (Thomaz, Biz \& Pavan, 2014).
This research highlights the need for better management of the \#CuritibaSuaLinda brand, accentuating the brand's name and emphasizing its unique features: original and exclusive local handmade products. The online strategy could be potentialized by the use of \#hashtags to engage potential customers and promote the artisans, and the brand. A social media campaign could be run, to promote new products and or explain more about the history of the artisans.

It is hoped that this study will add to theoretical discussions that will enable marketing in souvenir stores to be extended and strengthened, reinforcing the dissemination of products via both digital and physical platforms, creating a direct connection between the brand and the consumer. As practical implications, digital marketing is highlighted, as a tool for promoting sales expansion, brand visibility and engagement.

A suggestion for future research would be a detailed study of the target audience and the potential demand and further studies on the online reputation of the \#CuritibaSuaLinda and comparing it with similar stores that sell souvenirs.

\section{References}

Adi, P. H. (2015). Key successful indicators for small businesses' integrated marketing model. International Journal of Applied Business and Economic Research, 13(7), 4815-4829.

Akel, G. M. (2012). Reputação online no mundo da alimentação comercial: Um estudo comparativo entre Ourense (Espanha) e Curitiba (Brasil) (Doctoral dissertation, Dissertação de Mestrado apresentada para obtenção de título de Planificación y Dirección del Turismo Interior y de Salud. Facultad de Ciencias Empresariales y Turismo. Universidade de Vigo, Ourense).

Bem Paraná. (2018, setembro 19). Prefeitura inaugura nesta quinta-feira primeira loja \#CuritibaSuaLinda. Recuperado de https://bit.ly/2EBnOR3.

Boaria, F., Anjos, S. J. G. D., \& Raye, R. L. (2014). A aplicação do emarketing nas redes hoteleiras do Brasil. Tourism \& Management Studies, 10(2), 116-122.

Chen, H. L., \& Mathews, S. (2017). Experiential brand deployment: improving tourism brand evaluations. Journal of Hospitality \& Tourism Research, 41(5), 539-559.

Crescitelli, E., \& Freundt, V. A. (2013). Métricas de comunicação de marketing offline e online. Revista FSA (Centro Universitário Santo Agostinho), 10(2), 01-25.

Curitiba Space. 2019. Quem foi: Lange de Morretes?. Recuperado de https://bit.ly/3a5tzCv.

De Souza, T. A., \& Gandara, J. M. G. (2013). Mobiliário urbano como elemento de qualidade, marketing e sustentabilidade em Curitiba/PR. Revista Hospitalidade, (I). 
Domareski-Ruiz, T. C., Horodyski, G. S., \& Carniatto, I. V. (2019). A Economia Criativa e o Turismo: Uma Análise do Projeto Soucuritiba, de Curitiba-Paraná-Brasil. Revista Gestão e Desenvolvimento, 16(2), 145-169.

Dominici, G. (2009). From marketing mix to e-marketing mix: a literature overview and classification. International journal of business and management, 4(9), 17-24.

Eugênio, M. (2015). Mídias Sociais na Promoção de Marcas. Ecommerce Org. Recuperado em https://bit.ly/37aW5dp.

Font, X. (2009). Marketing responsible tourism, ICRT-LMU, Leeds.

Gabriel, M. (2010). Marketing na era digital: conceitos, plataformas e estratégias. Novatec Editora.

Gil, A. C. (2008). Métodos e técnicas de pesquisa social. 6. ed. Editora Atlas SA.

Horodyski, G. S. (2014). O Consumo na Experiência Turística: o caso dos souvenirs no destino Curitiba-PR (Doctoral dissertation, Tese de Doutorado. Programa de Pós Graduação em Geografia. Universidade Federal do Paraná. Curitiba).

Instituto Brasileiro de Geografia e Estatística. (2020). Cidades e Estados. Curitiba. Recuperado em https://bit.ly/355wYWI.

Instituto Municipal de Turismo de Curitiba. (2020). Loja \#CuritibaSuaLinda. Recuperado em https://bit.ly/2JFW32F.

Instituto Municipal de Turismo de Curitiba. (2020). Institucional. Dados e Estatísticas. Recuperado em https:// bit.ly/2VBeEBS.

Instituto Municipal de Turismo de Curitiba. (2020). Institucional. Missão e Visão. Recuperado em https://bit.ly/2WoJ6Ad.

Instituto Municipal de Turismo de Curitiba (2019). Desfile de moda inaugura a quarta e maior loja \#CuritibaSuaLinda. Recuperado de https://bit.ly/3rhuiQM.

Júnior, N. D. S. M., de Sousa, P. H. R., \& Demo, G. (2018). Análise do composto de marketing em empresas de turismo: um estudo bibliométrico. Turismo-Visão e Ação, 20(2), 324.

Kotler, P., \& Armstrong, G. (2007). Princípios de Marketing: 12. ed. São Paulo: Pearson Prentice Hall.

Kotler, P., Kartajaya, H., \& Setiawan, I. (2010). Marketing 3.0: From products to customers to the human spirit. In Marketing Wisdom (pp. 139-156). Springer, Singapore.

Kotler, P., \& Keller, K. L. (2006). Administração de Marketing. 12 ed. São Paulo: Pearson Prentice Hall.

Li, L., \& Buhalis, D. (2005, January). Predicting internet usage for travel bookings in China. In ENTER (pp. 429-439).

Liu, C. H. S., \& Chou, S. F. (2016). Tourism strategy development and facilitation of integrative processes among brand equity, marketing and motivation. Tourism Management, 54, 298-308.

Machado, C. D. M. N., Camfield, C. E. R., Cipolat, C., \& de Quadros, J. D. N. (2012). Os 4 P's do Marketing: uma Análise em uma
Empresa Familiar do Ramo de Serviços do Norte do Rio Grande do Sul. IX Simpósio de Excelência em Gestão e Tecnologia.

McCarthy, J. (1960). Programs with common sense (pp. 300-307). RLE and MIT computation center.

Mcities (2018, dezembro 26). Descubra Curitiba. Onde achar os souvenirs originais de Curitiba. Recuperado de http:// bit.ly/2K8bHnU.

Morrison, A. M. (2012). Marketing de hospitalidade e turismo. São Paulo: Cengage Learning, 22.

Müller, J. (2004). Elementos semióticos no planejamento urbano: o caso de Curitiba (Dissertação de mestrado em Geografia) Setor de Ciências da Terra, Universidade Federal do Paraná, Curitiba, PR. Recuperado de https://bit.ly/38mpRvk.

Prefeitura Municipal de Curitiba. (2019, abril 05). Notícias. Exposição leva os pontos turísticos para as estações-tubo. Recuperado de https://bit.ly/2VMZAhv.

Prefeitura Municipal de Curitiba. (2019). \#CuritibaSuaLinda ganha sua quarta e maior loja na terça-feira. Recuperado em https://bit.ly/2w/m1dx.

Prefeitura Municipal de Curitiba. (2020). Jardim Botânico ganha unidade da rede de lojas \#CuritibaSuaLinda. Recuperado em https://bit.ly/3nsHVdv.

Reino, L. S. A. (2012). Redes Sociais e marketing digital, o caso do Firula's Café. BOCC - Biblioteca Online de Ciências da Comunicação. Covilhã, Portugal.

Roque, V., Fernandes, G., \& Raposo, R. (2012). Identificação dos Media Sociais utilizados pelas organizações de gestão de destinos: o caso de estudo do destino turístico Serra da Estrela. Turismo \& Desenvolvimento, 2 (17-18), 225-234. 2012.

Silva Schuster, M. \& da Veiga Dias, V. (2019). A Mensuração de Personalidade Turística e sua Aplicação na Prática dos Agentes de Marketing Turístico Institucional e Social no Brasil. Turismo: Visão e Ação, Balneário Camboriú, 21(3).

Thomaz, G. M., Biz, A. A., \& Pavan, C. S. (2014). Análise das Ações de Marketing em Mídias Sociais pelas Destination Management Organizations (DMO): um Estudo Comparativo da Promoção Turística no Facebook1. Anais... XI, Universidade do Estado do Ceará-UECE.

URBS - URBANIZAÇÃO DE CURITIBA. (2019). Comunidade. Lojas \#CuritibaSuaLinda. Recuperado em https://bit.ly/2Kaztip.

Wichels, S. (2014). Comunicação Turística: desafios e tendências na contemporaneidade. Estudo de Caso: Tenerife (Master's thesis). 